\title{
Review Article Gut Helminth Infection-Induced Immunotolerance and Consequences for Human Papillomavirus Persistence
}

\author{
Eva H. Clark, ${ }^{1,2,3 *}$ Robert H. Gilman, ${ }^{4}$ Elizabeth Y. Chiao, ${ }^{5,6}$ and Patti E. Gravitt ${ }^{7}$ \\ ${ }^{1}$ Department of Medicine, Section of Infectious Diseases, Baylor College of Medicine, Houston, Texas; ${ }^{2}$ Department of Medicine, Section of Health \\ Services Research, Center for Innovations in Quality, Effectiveness, and Safety (IQuESt), Michael E. DeBakey VA Medical Center, Houston, Texas;

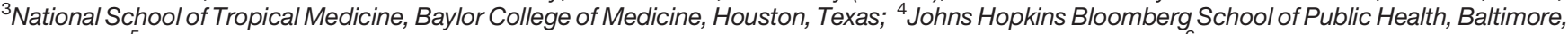 \\ Maryland; ' 5 Department of Epidemiology, University of Texas MD Anderson Cancer Center, Houston, Texas; ${ }^{6}$ Department of General Oncology, \\ University of Texas MD Anderson Cancer Center, Houston, Texas; ${ }^{7}$ Department of Epidemiology and Public Health, University of Maryland School of \\ Medicine, Baltimore, Maryland
}

\begin{abstract}
Cervical cancer, a malignancy caused by persistent human papillomavirus (HPV) infection, develops in more than 500,000 women annually. More than $90 \%$ of deaths from cervical cancer occur in low- and middle-income countries. A common epidemiological feature of countries with high cervical cancer incidence is a high burden of intestinal helminth infection. The ability of intestinal helminths to trigger immunoregulation, resulting in a "tolerogenic" systemic immune environment, provides fertile soil for the persistence of oncogenic viruses such as HPV. Animal models have shown that intestinal helminth infection permits the persistence of some viruses, however, HPV-specific and human studies are lacking. Large, well-organized trials evaluating the consequences of intestinal helminth infection on the human immune system and HPV persistence may lead to improved strategies for HPV prevention in helminth-endemic regions of the world. Additionally, such studies would offer insight into the specific ways that intestinal helminth infection contributes to immunomodulation, which could identify new therapeutic targets for a range of diseases, from inflammatory disorders to cancer. In this review, we discuss the evidence for helminth-induced systemic and local immune dysregulation, discuss possible mechanisms by which chronic intestinal helminth infection may facilitate HPV persistence, and suggest novel helminth-related interventions that could offer a high leverage (if somewhat unconventional) approach to HPV and cervical cancer control in resourceconstrained regions.
\end{abstract}

\section{INTRODUCTION}

Cervical cancer, caused by persistent high-risk human papillomavirus (hrHPV) infection, is the fourth most common female malignancy worldwide. ${ }^{1}$ Each year more than 500,000 women develop cervical cancer, resulting in more than 300,000 deaths. ${ }^{1}$ The global burden of cervical cancer highlights important disparities; for example, nearly $90 \%$ of women who die of cervical cancer live in low- and middle-income countries (LMICs). Reduced access to effective screening programs contributes to the disparity in cervical cancer incidence by failing to detect and treat precancers. ${ }^{2,3}$ However, lack of screening (which intervenes in only a minority [less than 10\%] of HPVinfected women with high-grade epithelial abnormalities) does not completely explain the higher population prevalence of human papillomavirus (HPV) across the lifespan in LMICs. ${ }^{4}$ The increased prevalence of HPV in LMICs often directly correlates with invasive cervical cancer incidence ${ }^{5}$; therefore, it is possible that there are additional underlying epidemiological constructs unique to LMICs that contribute to those countries' elevated cervical HPV prevalence and cancer rates.

A common epidemiological feature of countries with high cervical cancer incidence is a high burden of intestinal infection with immune modulating helminths. Chronic helminth infection across the lifespan may compromise immune control of cervical HPV infection, increasing the duration of detectable infection and thus population prevalence of HPV across the lifespan. In a direct test of this hypothesis

${ }^{*}$ Address correspondence to Eva H. Clark, Houston HSR\&D Center for Innovations in Quality, Effectiveness and Safety (IQuESt), Baylor College of Medicine, Michael E. DeBakey VA Medical Center, 2450 Holcombe Blvd., Suite 01Y, Houston, TX 77021. E-mail: eva.clark@ bcm.edu in the Peruvian Amazon region, women infected with one or more intestinal helminths (e.g., Ascaris, Trichuris, hookworm) had a $60 \%$ higher HPV prevalence, which was not confounded by differences in sexual behaviors or other sociodemographic characteristics. Careful examination of secretions from the uterine cervix provided evidence of local mucosal immune dysregulation in intestinal helminthinfected women, who showed a type 2 helper T cell (Th2)polarized immune signature. ${ }^{6}$

In this review, we take a broader look at the evidence for systemic immune dysregulation associated with intestinal helminth infections, discuss possible mechanisms by which chronic intestinal helminth infection may facilitate HPV persistence, and suggest novel approaches to HPV and cervical cancer control in resource-constrained regions, which struggle to implement more complex early detection and treatment interventions for cervical cancer.

\section{NATURAL HISTORY OF HPV INFECTION}

Human papillomavirus infection represents a heterogenous state of infection, where an infected individual may harbor one or more of the 100 subtypes of HPV, at least 13 of which are identified as high-risk, causal agents of cervical cancer (hrHPV). ${ }^{7,8}$ The average age of HPV acquisition is 20 years, and approximately $80 \%$ of sexually active women will acquire at least one HPV genotype by age 50 years. ${ }^{9}$ Women with more sexual exposure (i.e., a higher number of sexual partners by themselves or their partners) are likely to acquire multiple HPV infections over their sexual lifespan. ${ }^{10,11}$ In short-term follow-up of newly acquired HPV in observational studies, more than $90 \%$ of HPV infections become undetectable within 6-18 months of initial infection. ${ }^{12,13}$ Although often referenced as representing viral 
clearance, the natural history of accumulating HPV infections over time is often more complex. Human papillomavirus infections of cervical epithelial cells are asymptomatic, do not produce viremia, and are identified solely through nucleic acid testing of exfoliated epithelial cells. ${ }^{11}$ At any given time, HPV infections may be detectable, active infections (demonstrated via nucleic acid amplification test), or may remain undetectable in exfoliated cells while retained in the basal cervical epithelium. ${ }^{14-17}$

It is increasingly recognized that much of the detectable HPV prevalence at a population level, particularly in women well past sexual debut, represents the loss of control of latent HPV infections. ${ }^{18-21}$ While transient-reactivated infections appear to pose little immediate risk for progression to invasive disease, ${ }^{22}$ persistently detectable hrHPV infection for 2 years or more has a significantly higher risk of progression to advanced neoplasia and cancer. ${ }^{23,24}$ Detectable hrHPV likely is in an active phase of oncogene expression, leading to persistent exposure of cervical epithelial cells to oncogenic proteins and thus loss of several key apoptotic functions that would otherwise be triggered in the event of DNA damage. The longer cervical epithelial cells are exposed to oncogene expression, the higher their risk of accumulating other cancer-causing mutations during unchecked replication, leading to selection of a transformed cellular phenotype. This process, in combination with a permissive immune microenvironment, would tip the scales in favor of malignant transformation and progression.

\section{PERSISTENT HPV INFECTION REQUIRES A TOLEROGENIC IMMUNE ENVIRONMENT}

The persistent detectable state of HPV infection reflects a chronic loss of immunologic control. Studies showing increased prevalence of HPV infection and associated anogenital disease among immunosuppressed populations, including solid organ transplant recipients ${ }^{25,26}$ and people living with HIV infection, ${ }^{27-29}$ provide evidence emphasizing the importance of cell-mediated immunity in HPV control. Most studies indicate that worse control of HIV disease and greater immunologic deficit are associated with higher HPV prevalence ${ }^{27,30}$ and longer persistence of HPV infection, ${ }^{31-33}$ though others suggest that positive HIV status independent of CD4 count influences risk of HPV infection and dysplasia. ${ }^{34,35}$

In immunocompetent subjects, an effective type 1 helper $T$ cell (Th1) response is necessary for HPV control-and lack of an effective Th1 response is associated with persistent HPV infection (Figure 1). ${ }^{15}$ Although in vitro and in vivo studies of host immunologic control of HPV infection have yielded disparate results, ${ }^{36}$ available data suggest that certain cytokines (including tumor growth factor- $\beta$ [TGF- $\beta]$, tumor necrosis factor- $\alpha$ [TNF- $\alpha]$, interleukin-1 [IL-1], the type I interferons, and interferon- $\gamma$ [IFN- $\gamma]$ ) may act to inhibit proliferation of HPV-infected cervical epithelial cells. ${ }^{37-40}$ One study of cytokine mRNA patterns in exfoliated cervical cells demonstrated that women who controlled their HPV infections within 4 months had a Th1 profile (specifically, expression of IFN- $\gamma$ mRNA and absence of IL-4 mRNA) preceding clearance, compared with highly variable patterns in HPV-negative women, ${ }^{41}$ though other studies have found no difference in cytokine profiles or $\mathrm{T}$ cell subsets of cervical secretion specimens. ${ }^{42}$ Cervical biopsy studies have demonstrated decreased IFN- $\gamma$
mRNA expression in women with cervical dysplasia or cancer compared with those with normal cervical tissue, ${ }^{43}$ as well as evidence for local transition from Th1 cytokine (e.g., IL-2, IL-12, and TNF- $\alpha$ ) predominance to Th2 (e.g., IL-4) to regulatory/immunomodulatory (Treg, e.g., TGF- $\beta$ and IL-10) as normal cervical epithelium progresses to cancer. ${ }^{44,45}$ Studies of stimulated peripheral blood lymphocytes have suggested that such local changes in cytokine polarization are mirrored by the systemic immune environment during HPV infection as cervical dysplastic disease worsens. ${ }^{46,47}$ Although host defense mechanisms are largely effective at controlling initial HPV infection in immunocompetent individuals, ${ }^{12}$ exposure to agents that cause a tolerogenic systemic immune environment could plausibly facilitate hrHPV persistence, leading to an increased risk of developing cervical cancer.

\section{CHRONIC GUT HELMINTH INFECTION PROMOTES A TOLEROGENIC SYSTEMIC IMMUNE ENVIRONMENT}

Hundreds of thousands of individuals living in LMICs are infected with one or more multicellular, parasitic worms called helminths. ${ }^{48}$ The largest group of clinically relevant helminths are nematodes (roundworms). In this review, we focus on nematodes that reside in the human gut (intestinal helminths). Examples of intestinal helminths include Enterobius vermicularis (pinworm), Trichuris trichiura (whipworm), Strongyloides stercoralis (threadworm), Ascaris lumbricoides, and Necator americanus and Ancylostoma duodenale (hookworms). As intestinal helminths acutely infect their human hosts and migrate to the human gut, intestinal helminths activate first innate lymphocytes and then effector CD4 T cells, which induce Th2 immune responses ${ }^{49-51}$ (Figure 2), characterized by production of cytokines such as IL-4, IL-5, and IL-13. ${ }^{52,53}$ This cascade has many important downstream effects, including enhanced epithelial mucous production, smooth muscle contraction, eosinophilia, immunoglobulin E production, tuft and goblet cell production, and differentiation of alternatively activated macrophages, which help rid the host of the intestinal helminth infection and prevent reinfection. ${ }^{54,55}$ Additionally, activation of Th2 responses downregulates proinflammatory Th1 and Th17 pathways, which are associated with control of viral diseases such as HPV, among other pathogens.

Following the initial induction of strong Th2 immune responses, adult intestinal helminths eventually establish chronic infection in the human gut and must regulate their host's immune system to ensure their long-term survival. ${ }^{56}$ This process includes induction of regulatory $T$ cells (Tregs), which promote systemic immunotolerance. Specifically, persistence of Th2 immune responses leads to expansion of natural and helminth-induced Tregs. ${ }^{52,57}$ Regulatory T cells represent a lineage of helper $T$ cells characterized by expression of transcription factor Foxp3 and secretion of suppressive cytokines like IL-10 and TGF- $\beta$. They modulate the immune response by downregulating $T$ cell activity, suppressing innate immune cells, and expressing suppressor molecules such as cytotoxic T lymphocyte antigen-4 (CTLA-4). ${ }^{58}$ Although a large body of literature supports helminthinduced immunomodulation (Table 1), most relevant studies relied on animal models ${ }^{57,59-63}$ or small human trials. Of the published human studies, most evaluated tissue invasive helminths (e.g., filaria [invasive nematodes] and Schistosoma 


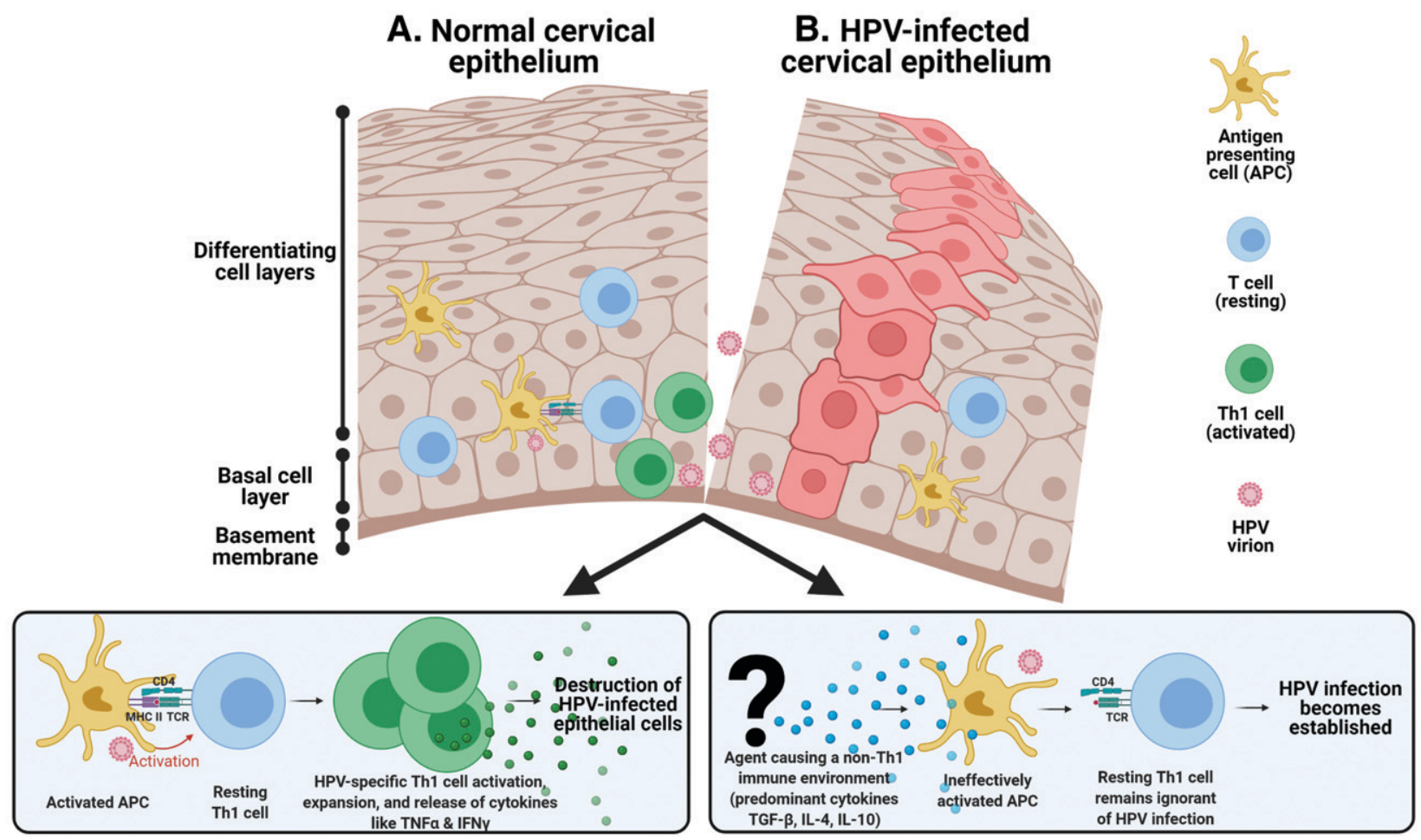

FIGURE 1. Hypothesized role of the adaptive immune system in control of HPV. The cervical basal endothelium is exposed to human papillomavirus (HPV) via microbreaks in the epithelial layer. (A) In individuals with normal nonpolarized immune systems, resting T cells (blue circular cells) and antigenpresenting cells (APCs; yellow cells) exist in the lower layers of the epithelium. APCs take up and present HPV antigens to Th1 cells (green circular cells), leading to expansion of HPV-specific Th1 cells that contribute to destruction of infected epithelial cells. (B) If an efficient adaptive immune response does not occur (e.g., due to any agent that facilitates a "tolerogenic" immune environment), active HPV infection may establish in the basal epithelial cells. Epithelial cells containing the HPV genome (red cells) migrate toward the epithelial surface. Persistent and/or prolonged high-risk human papillomavirus (hrHPV) infection can lead to cervical dysplasia. Figure created with BioRender.com. IFN- $\gamma=$ interferon- $\gamma$; IL $=$ interleukin; Th1 $=\mathrm{T}$ helper type 1 ; TNF = tumor necrosis factor.

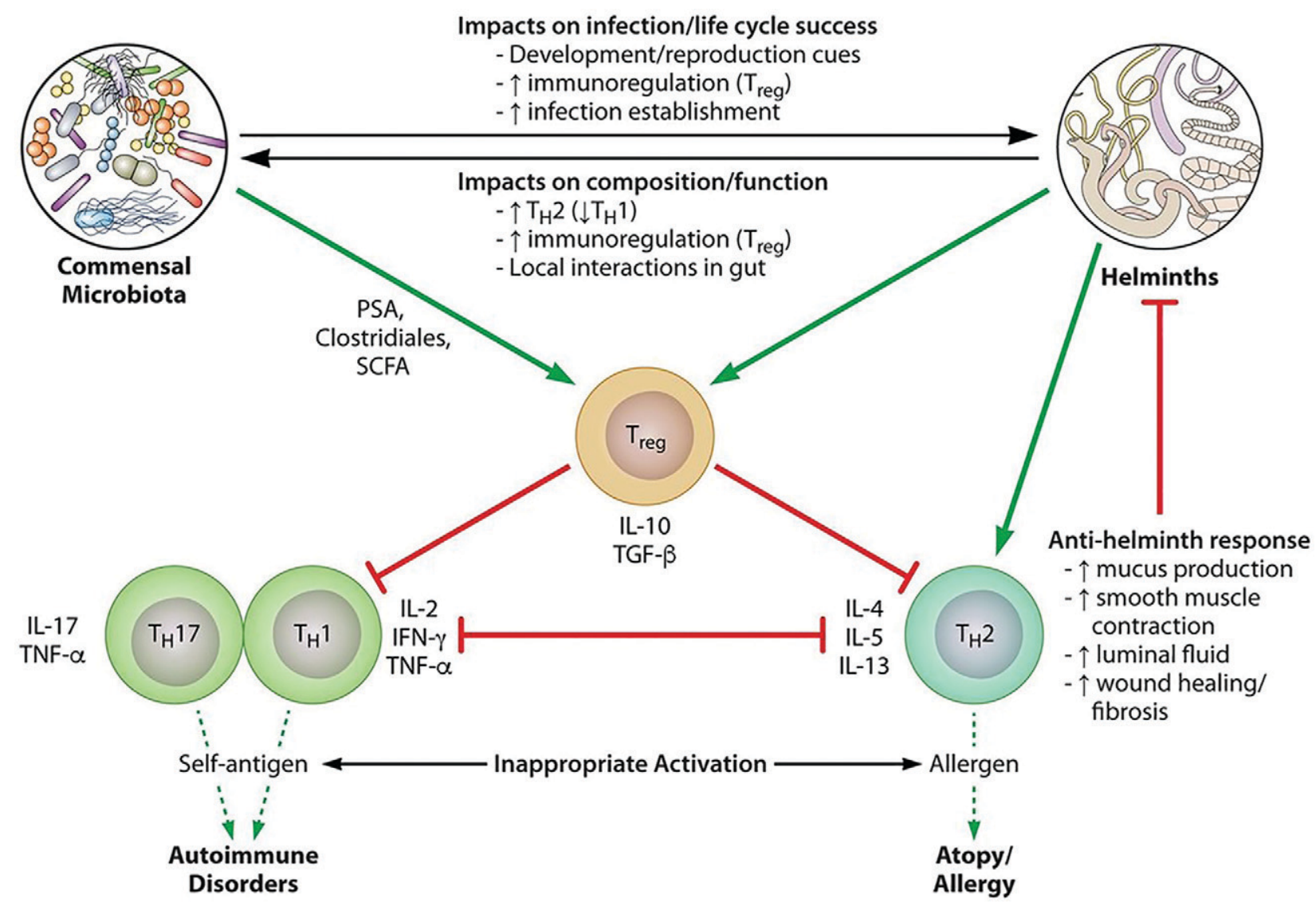

FIGURE 2. Outline of key interactions between helminths, the bacterial gut microbiota, and the host immune system. These interactions support the hypothesis that immunomodulatory influences of commensal bacteria and helminths can promote a tolerance phenotype. ${ }^{143} \mathrm{IL}=$ interleukin; $\mathrm{PSA}=$ polysaccharide A; SCFA = short-chain fatty acids; TGF = tumor growth factor; Th1 = type 1 helper T cell; Th2 = type 2 helper T cell; TNF = tumor necrosis factor; Treg = regulatory T cell. 
TABLE 1

Published evidence for helminth-induced systemic immunomodulation

\begin{tabular}{|c|c|c|c|}
\hline Topic & Study type & Helminth studied & $\operatorname{Ref}(\mathrm{s})$ \\
\hline \multicolumn{4}{|l|}{ Helminth production of cytokine mimics and antagonists } \\
\hline - Identification of two TGF- $\beta$ homologues in Brugia malayi & In vitro & Filaria & 49 \\
\hline $\begin{array}{l}\text { - Identification of a TGF- } \beta \text { homologue in B. malayi and Brugia } \\
\text { pahangi }\end{array}$ & In vitro & Filaria & 77 \\
\hline $\begin{array}{l}\text { - Nematode cystatins have multiple, specific capacities for host } \\
\text { immunomodulation }\end{array}$ & In vitro & Filaria & 90 \\
\hline $\begin{array}{l}\text { - Ascaris suum-derived products induce human neutrophil } \\
\text { activation }\end{array}$ & In vitro & STH & 88 \\
\hline $\begin{array}{l}\text { - Helminth-derived molecules share cross reactive epitopes with } \\
\text { the host IFN- } \gamma\end{array}$ & Mouse & Trichuris muris & 62 \\
\hline \multicolumn{4}{|l|}{$\begin{array}{l}\text { Depletion of regulatory } \mathrm{T} \text { cells in mouse models results in } \\
\text { helminth clearance }\end{array}$} \\
\hline $\begin{array}{l}\text { - Regulatory T cells depletion during early infection leads to } \\
\text { reduced helminth burden; absence of Tregs does not interfere } \\
\text { with the generation of protective memory }\end{array}$ & Mouse & Strongyloides ratti & 59 \\
\hline $\begin{array}{l}\text { - Early Treg depletion post infection results in expedited helminth } \\
\text { clearance and is associated with reduced Th1-mediated } \\
\text { inflammation of the intestine }\end{array}$ & Mouse & Trichuris muris & 60 \\
\hline \multicolumn{4}{|l|}{ Helminth infection can increase host regulatory $\mathrm{T}$ cell activity } \\
\hline $\begin{array}{l}\text { - Heligmosomoides polygyrus excretory-secretory antigen } \\
\text { induced de novo Foxp3 expression but did not promote Th1 or } \\
\text { Th2 development }\end{array}$ & Mouse & Heligmosomoides polygyrus & 57 \\
\hline $\begin{array}{l}\text { - Helminth infection is associated with polyclonal expansion of } \\
\text { Foxp3 }(+) \text { Helios }(+) C D 4(+) \text { thymic (t)Tregs in the gut and } \\
\text { periphery }\end{array}$ & Mouse & Heligmosomoides polygyrus & 61 \\
\hline $\begin{array}{l}\text { - Strongyloides ratti infection induces expansion of Foxp3 + } \\
\text { regulatory T cells that interfere with immune response and } \\
\text { parasite clearance in BALB/c mice }\end{array}$ & Mouse & Strongyloides ratti & 59 \\
\hline $\begin{array}{l}\text { - Schistosoma antigen induces Foxp3 expression in naïve T cells } \\
\text { in a TGF- } \beta \text {-dependent manner }\end{array}$ & Mouse & Schistosoma & 85 \\
\hline $\begin{array}{l}\text { - Th2 and regulatory T cell populations expand during STH } \\
\text { infections }\end{array}$ & Human & STH & 51 \\
\hline \multicolumn{4}{|l|}{ Helminth infection can decrease host immune responsiveness } \\
\hline $\begin{array}{l}\text { - Helminth infections are associated with a generalized } \\
\text { suppression of cytokine responses to mitogen }\end{array}$ & Human & STH & 87 \\
\hline $\begin{array}{l}\text { - Microfilaremia is associated with specific cellular immune } \\
\text { unresponsiveness }\end{array}$ & Human & Filaria & 64 \\
\hline $\begin{array}{l}\text { - Low numbers of parasite-specific } T \text { and } B \text { cells may be partially } \\
\text { responsible for severely diminished immunoresponsiveness in } \\
\text { patients with filariasis }\end{array}$ & Human & Filaria & 65 \\
\hline $\begin{array}{l}\text { - Patients with filariasis have fewer IFN- } \gamma \text {-secreting lymphocytes. } \\
\text { Neutralizing anti-IL-10 or anti-TGF- } \beta \text {-enhanced lymphocyte } \\
\text { proliferation response to filarial antigens }\end{array}$ & Human & Filaria & 66 \\
\hline $\begin{array}{l}\text { - Significant proportions of patients with filariasis show antigen- } \\
\text { specific lymphocyte unresponsiveness, and lymphocyte } \\
\text { proliferation to filarial antigens correlated negatively with } \\
\text { specific lgG4 levels }\end{array}$ & Human & Filaria & 67 \\
\hline $\begin{array}{l}\text { - High levels of IL-10 production are associated with antigen- } \\
\text { specific hyporesponsiveness in human lymphatic filariasis }\end{array}$ & Human & Filaria & 71 \\
\hline $\begin{array}{l}\text { - Antigen-specific cellular hyporesponsiveness in a chronic filarial } \\
\text { infection is mediated by IL-10 and TGF- } \beta\end{array}$ & Human & Filaria & 74 \\
\hline $\begin{array}{l}\text { - Interleukin-10 downregulates filarial antigen-driven type } 1 \\
\text { responses }\end{array}$ & Human & Filaria & 72 \\
\hline $\begin{array}{l}\text { - Cellular responses to filaria infection are vigorous early on but } \\
\text { are down-regulated as infection becomes chronic partly via IL- } \\
\text { 10-dependent mechanism }\end{array}$ & Human & Filaria & 73 \\
\hline $\begin{array}{l}\text { - Interleukin-10 contributes to parasite antigen-induced T cell } \\
\text { hyporesponsiveness in patients with chronic schistosomiasis }\end{array}$ & Human & Schistosoma & 81 \\
\hline $\begin{array}{l}\text { - Interleukin-10 modulates in vitro granuloma formation in } \\
\text { schistosomiasis patients }\end{array}$ & Human & Schistosoma & 82 \\
\hline $\begin{array}{l}\text { - Interleukin-10 has an important immunomodulatory role in } \\
\text { patients with chronic asymptomatic schistosomiasis }\end{array}$ & Human & Schistosoma & 83 \\
\hline \multicolumn{4}{|l|}{$\begin{array}{l}\text { Chronic helminth infection leads to skewed cytokine profiles } \\
\text { (particularly towards IL-10 and TGF- } \beta \text { ) }\end{array}$} \\
\hline $\begin{array}{l}\text { - T cells from onchocerciasis patients produce large amounts of } \\
\text { IL-10 }\end{array}$ & Human & Filaria & 78 \\
\hline $\begin{array}{l}\text { - Children in STH hyperendemic regions secrete more IL-10 and } \\
\text { TGF- } \beta\end{array}$ & Human & STH & 86 \\
\hline \multirow{2}{*}{$\begin{array}{l}- \text { A large proportion of children with STH infections produce IL-10 } \\
\text { Helminth antigen-specific responses recover after anti-helminth treatment }\end{array}$} & Human & STH & 87 \\
\hline & Human & Filaria & 68 \\
\hline
\end{tabular}


TABLE 1

Continued

\begin{tabular}{|c|c|c|c|}
\hline Topic & Study type & Helminth studied & $\operatorname{Ref(s)}$ \\
\hline \multicolumn{4}{|l|}{$\begin{array}{l}\text { - T cell proliferative responses to B. malayi antigen and } \\
\text { production of IFN- } \gamma \text { by stimulated mononuclear cells increased } \\
\text { significantly after DEC treatment }\end{array}$} \\
\hline $\begin{array}{l}\text { - Cellular responses to Schistosoma antigens vary but poor } \\
\text { responsiveness is frequent among those with severe disease. } \\
\text { Responses improve after treatment. }\end{array}$ & Human & Schistosoma & 79 \\
\hline $\begin{array}{l}\text { - Chronic infection with Schistosoma haematobium is associated } \\
\text { with the reversible downregulation of T cell proliferative } \\
\text { responses and IL-4 release }\end{array}$ & Human & Schistosoma & 80 \\
\hline \multicolumn{4}{|l|}{ Regulatory $T$ cell levels decrease after anti-helminth treatment } \\
\hline $\begin{array}{l}\text { - Regulatory T cells }\left(\mathrm{CD} 3^{+} / \mathrm{CD} 4^{+} / \mathrm{CD} 25^{\text {high }}\right) \text { decrease after anti- } \\
\text { Schistosoma mansoni treatment }\end{array}$ & Human & Schistosoma & 84 \\
\hline $\begin{array}{l}\text { Use of helminth infection as therapy for inflammatory diseases } \\
\text { - Interleukin-22 }+\mathrm{CD} 4+\mathrm{T} \text { cells are associated with therapeutic } \\
\text { Trichuris trichiura infection in an ulcerative colitis patient }\end{array}$ & Human & STH & 91 \\
\hline $\begin{array}{l}\text { - Helminth-infected MS patients have fewer exacerbations; IL-10 } \\
\text { and TGF- } \beta \text { production and CD25 + CD4 + FoxP3 + T cell } \\
\text { levels increase after helminth infection }\end{array}$ & Human & $\mathrm{STH}+{ }^{*}$ & 92 \\
\hline
\end{tabular}

[flukes] ${ }^{49,64-85}$; few have focused on intestinal helminths. ${ }^{51,86-88}$ Studies of antihelminth treatment have shown that deworming decreases CTLA-4 expression on CD4 T cells, alleviating key $\mathrm{T}$ cell suppressor activity. ${ }^{51,89}$

As intestinal helminths reside within the gastrointestinal tract, they can alter the gut microbiome (Figure 2), ${ }^{93}$ a major regulator of the systemic immune system. ${ }^{94}$ Disruption of the normal bacterial gut flora by helminth infection may represent a second pathway by which helminths indirectly contribute to systemic immunotolerance. Dysbiosis of the gut microbiota is known to contribute to many chronic diseases including cancer. ${ }^{95-97}$ Although there are studies exploring helminth-induced changes to the distribution of gut flora in animals, ${ }^{98-102}$ few have translated this knowledge to robust investigation in humans, ${ }^{103-106}$ and results of these studies have been disparate. Most existing studies of how the helminth-infected gut microbiome affects host immunity have been conducted in animal models. ${ }^{107}$ Several in vivo studies support the idea that intestinal helminth and bacteria species may interact to promote systemic immunomodulation, allowing for symbiotic persistence in the gut. Rodent helminths are known to secrete molecules that mimic cytokines like TGF- $\beta^{108}$ and exploit the host's own regulatory mechanisms to induce Foxp3 + Treg cells, ${ }^{57}$ as do various intestinal bacteria including Bifidobacterium infantis, ${ }^{109} \mathrm{Bac}-$ teroides fragilis, ${ }^{110}$ Clostridium spp., ${ }^{111-113}$ and Lactobacillus spp. ${ }^{114,115}$ In one study, mice lacking microbiota-inducible Tregs had greater resistance to infection with murine helminth Heligmosomoides polygyrus, implying that Treg induction by the microbiota promotes $H$. polygyrus persistence. ${ }^{116}$ Other studies provide further evidence for shared immune dysregulation between Treg-promoting helminths and gut microbiota by showing that $H$. polygyrus increased Lactobacillus taiwanensis abundance in the murine gut and the administration of $L$. taiwanensis increased $H$. polygyrus burdens. ${ }^{117-119}$ Other coinfection experiments demonstrate that helminth-induced $\mathrm{T}$ cell responses can inhibit the growth of certain bacterial pathogens. $^{120-122}$

\section{CHRONIC INTESTINAL HELMINTH-INDUCED SYSTEMIC IMMUNOMODULATION MAY ALLOW FOR VIRAL PERSISTENCE}

Because intestinal helminths affect billions of people living in LMICs, intestinal helminth-induced immunomodulation has a significant potential impact on coinfections (including oncogenic viruses like HPV, hepatitis B virus, and Kaposi sarcoma herpes virus [KSHV]). Most published data evaluating the effect of helminth infection on concomitant and/or persistent viral infection are from animal research. Studies of mice chronically infected with murine gammaherpesvirus-68 (MHV68, which is closely related to KSHV) demonstrate that coinfection with $H$. polygyrus (an intestinal helminth) and Schistosoma mansoni (a tissue invasive helminth) triggers reactivation of latent MHV68. In these studies, the Th2 cytokine IL-4 was sufficient to promote viral reactivation and prevent the development of Th1-dependent antiviral immune responses. ${ }^{123}$ Similarly, studies of mice infected with Trichinella spiralis (a tissue invasive helminth) have demonstrated elevated levels of murine norovirus (MNV) replication and decreased MNV-specific $\mathrm{T}$ cell responses in coinfected mice. ${ }^{124}$ Another murine study showed that Ascaris suum (an intestinal helminth) and Vaccinia virus coinfection may downmodulate the Vaccinia-specific immune response, allowing for increased virus-associated pathology. ${ }^{125}$ Collectively, these animal model studies suggest that helminth infection impairs the development of protective, anti-viral immune responses, increasing persistence and/or pathogenicity of virus coinfections. $^{126,127}$

In humans, intestinal helminth-virus coinfection has primarily been studied in people living with HIV infection. These studies suggest that the CD4 T cells of helminth-infected individuals are more susceptible to HIV infection because of helminth-induced chronic immune activation ${ }^{128}$ and because the chemokine coreceptors necessary for HIV infection of CD4 T cells are upregulated in helminth-infected individuals. ${ }^{129,130}$ Additionally, antiviral Th1 responses are suppressed due to helminth-associated Th2 lymphocyte propagation, ${ }^{131}$ and 
intestinal helminth-HIV coinfected individuals have higher levels of eosinophilia, increased immunoglobulin (Ig) E levels, and increased levels of additional immunosuppressive cytokines. $^{132,133}$ Several small studies indicate that treating helminth infections in adults with HIV may have small, shortterm favorable effects on markers of HIV disease progression, but larger, more robust studies are needed to confirm these findings. ${ }^{134,135}$ Importantly, studying the impact of helminth infection in the setting of HIV coinfection is difficult due to the overwhelming immune suppression that is caused by uncontrolled HIV, which may mask or overpower any effect helminths have on the human immune system.

Even fewer human studies have explored the relationship between helminth infection and oncogenic virus infection. In one such study, S. mansoni infection was correlated with increased seroprevalence of KHSV in Ugandan fishing communities. ${ }^{136}$ Given that seroconversion and antibody titer boosting are expected in the presence of viral reactivation, these human data are consistent with the findings from murine studies that suggested helminth-induced MHV68 reactivation. ${ }^{123}$ A study evaluating hrHPV and parasite coinfection in humans found higher hrHPV prevalence in Peruvian women with intestinal helminth infections than in uninfected or intestinal protozoa-only infected women. ${ }^{6}$ Furthermore, in this study, the Th2 cytokine IL-4 was strongly correlated with multiple cytokines and chemokines involved in the initiation and effector function of Th2 responses (e.g., IL-25, IL-21, IL-5, $\mathrm{IL}-10, \mathrm{IL}-8$, and IL-31) in the cervical fluid of intestinal helminth-infected women compared with uninfected women. This cytokine profile pattern suggests induction of a local, Th2-polarized immune response at the cervical mucosa in women with intestinal helminth infections, which provides biologically plausible evidence for intestinal helminth-induced suppression of antiviral (i.e., Th1) responses at the site of hrHPV infection, allowing for persistent replication of hrHPV in cervical epithelial cells.

\section{PUTTING IT ALL TOGETHER: INTESTINAL HELMINTH- INDUCED IMMUNE MECHANISMS COULD FACILITATE HRHPV PERSISTENCE AND EVENTUAL PROGRESSION TO CERVICAL CANCER}

Though precisely how chronic intestinal helminth infection may influence hrHPV coinfection persistence and progression to cervical cancer remains unknown, we can speculate as to potential mechanisms based on the studies outlined above. Chronic intestinal helminth infection promotes both a tolerogenic systemic immune environment and a Th2 polarized local cervical immune environment. The resultant non-Th1-polarized local immune environment-whether skewed towards Th2 or Treg activity-provides fertile ground for a virus like hrHPV to proliferate and infect cervical epithelial cells (Figure 1). By downregulating local Th1 pathways, intestinal helminth infection may allow for reactivation of latent $\mathrm{hrHPV}$ and promotion of hrHPV replication, as has been shown for MHV68. ${ }^{123}$ As hrHPV infection takes hold, the viral genome produces oncoproteins that can downregulate proinflammatory host immune mechanisms and prevent apoptosis of infected cervical epithelial cells. ${ }^{137-139}$ Intestinal helminth-hrHPV coinfection may facilitate perpetuation of an increasingly Treg-polarized local immune environment. Thus, this transition of the cervical immune milieu from Th1 cytokine predominance to Th2 cytokine predominance to tolerogenic cytokine predominance during coinfection allows for continued proliferation of hrHPVinfected epithelial cells, longer duration of expression of viral oncoproteins, and subsequent development of invasive cervical cancer. ${ }^{44,45}$

\section{APPLICATIONS OF IMPROVED UNDERSTANDING OF THE INTESTINAL HELMINTH-HPV RELATIONSHIP}

New studies are needed to expand the understanding of gut parasite-microbiota-immune system interactions. Specific areas of research that should be targeted include:

1. How the presence of helminths in the human gut directly and indirectly influences both the systemic and local (i.e., cervical) immune environment (with particular focus on immunologic mechanisms distinguishing between homeostatic and pathogenic helminth-host interactions).

2. The immunologic relationship between intestinal helminths and gut microbiota and how differential proportions of microbiota genera (and introduction of new microbiota in the form of pre- and/or probiotics) influence helminthrelated immunomodulation.

3. The long-term impact of regular treatment with medications commonly used for deworming (e.g., albendazole, mebendazole, ivermectin, and praziquantel) on the systemic immune system and the prevalence of chronic diseases and infections exacerbated by intestinal helminth infection.

A more specific understanding of parasite-microbiotaimmune system interactions would facilitate the development of scenario analyses to evaluate the broader impact of helminth treatment across multiple disease outcomes, balancing infection control (e.g., deworming could alter host susceptibility to other bacterial and/or parasitic infections and make vaccines more effective in helminth-endemic regions ${ }^{140}$ ) and autoimmunity. Longitudinal pre- and posthelminth treatment studies could answer many of these questions. At the individual level, such studies would provide more robust immunologic data and require smaller numbers of participants than larger ecological studies. These studies could then be followed by community-based trials to examine the effects of deworming at the population level.

From a public health perspective, if deworming through mass drug administration and water, sanitation, and hygiene (WASH) interventions lowers HPV persistence through elimination of concomitant immune dysfunction, cancer risk in affected women could be significantly reduced using widely available, low-cost interventions. If decreasing helminth burden reduces HPV prevalence by shortening the duration of active, detectable infection, fewer women will test positive in HPV screening, increasing the feasibility of implementation and reducing costs associated with early detection and treatment programs. Bundling HPV and parasite control in community interventions may thus represent a systems-level health intervention with outcomes greater than the sum of its parts. Further, such large-scale deworming strategies - and, potentially, correction of intestinal dysbiosis (e.g., providing pre- or probiotics) - could revolutionize the treatment of gut helminth infections. Currently, most mass deworming programs target 
school-age children, not reproductive-age adult women. Although school-based programs are less expensive, modeling studies suggest that community-based deworming would be more cost-effective, even when modeling health benefits only among children. ${ }^{141}$ By demonstrating substantial health benefits to a wider population of adults, such programs could further promote broader policies supporting communitybased, mass deworming of reproductive-age women. ${ }^{142}$

\section{CONCLUSION}

The ability of intestinal helminths to trigger immunoregulation, resulting in a "tolerogenic" systemic immune environment, provides fertile soil for the persistence of oncogenic viruses such as HPV. Animal models have shown that intestinal helminth infection permits the persistence of some viruses; however, HPV-specific and human studies are lacking. Large, well-organized trials evaluating the consequences of intestinal helminth infection on the human immune system and HPV persistence may lead to improved strategies for HPV prevention in helminth-endemic regions of the world. Additionally, such studies would offer insight into the specific ways that intestinal helminth infection contributes to immunomodulation, which could identify new therapeutic targets for a range of diseases, from inflammatory disorders to cancer.

Received February 17, 2021. Accepted for publication May 10, 2021. Published online July 19, 2021.

Financial support: This work was supported by VA Health Services Research \& Development Center of Innovation grant CIN 13-413 (E. H. C. receives salary support in part from the Houston VA HSR\&D Center for Innovations in Quality, Effectiveness and Safety [CIN13-413] Advanced Fellowships Program in Health Services Research).

Authors' addresses: Eva H. Clark, Department of Medicine, Section of Infectious Diseases, Baylor College of Medicine, Houston, TX, Department of Medicine, Section of Health Services Research, Center for Innovations in Quality, Effectiveness, and Safety (IQuESt), Michael E. DeBakey VA Medical Center, Houston, TX, and National School of Tropical Medicine, Baylor College of Medicine, Houston, TX, E-mail: eva.clark@bcm.edu. Robert H. Gilman, Johns Hopkins Bloomberg School of Public Health, Baltimore, MD, E-mail: gilmanbob@gmail. com. Elizabeth Y. Chiao, Department of Epidemiology, University of Texas MD Anderson Cancer Center, Houston, TX, and Department of General Oncology, University of Texas MD Anderson Cancer Center, Houston, TX, E-mail: eychiao@mdanderson.org. Patti E. Gravitt, Department of Epidemiology and Public Health, University of Maryland School of Medicine, Baltimore, MD, E-mail: pgravitt@som. umaryland.edu.

\section{REFERENCES}

1. Bray F, Ferlay J, Soerjomataram I, Siegel RL, Torre LA, Jemal A, 2018. Global cancer statistics 2018: GLOBOCAN estimates of incidence and mortality worldwide for 36 cancers in 185 countries. CA Cancer J Clin 68: 394-424.

2. Lemp JM et al., 2020. Lifetime prevalence of cervical cancer screening in 55 low- and middle-income countries. JAMA 324: 1532-1542.

3. Peto J, Gilham C, Fletcher O, Matthews FE, 2004. The cervical cancer epidemic that screening has prevented in the UK. Lancet 364: 249-256.

4. Bruni L, Diaz M, Castellsague X, Ferrer E, Bosch FX, de Sanjose $S, 2010$. Cervical human papillomavirus prevalence in 5 continents: meta-analysis of 1 million women with normal cytological findings. J Infect Dis 202: 1789-1799.
5. Maucort-Boulch D, Franceschi S, Plummer M, Group IHPSS, 2008. International correlation between human papillomavirus prevalence and cervical cancer incidence. Cancer Epidemiol Biomarkers Prev 17: 717-720.

6. Gravitt PE et al., 2016. Soil-transmitted helminth infections are associated with an increase in human papillomavirus prevalence and a T-Helper Type 2 cytokine signature in cervical fluids. J Infect Dis 213: 723-730.

7. Walboomers JM, Jacobs MV, Manos MM, Bosch FX, Kummer JA, Shah KV, Snijders PJ, Peto J, Meijer CJ, Munoz N, 1999. Human papillomavirus is a necessary cause of invasive cervical cancer worldwide. J Pathol 189: 12-19.

8. Munoz N, Bosch FX, de Sanjose S, Herrero R, Castellsague X, Shah KV, Snijders PJ, Meijer CJ, International Agency for Research on Cancer Multicenter Cervical Cancer Study G, 2003. Epidemiologic classification of human papillomavirus types associated with cervical cancer. $N$ Engl J Med 348: 518-527.

9. Moscicki AB, 2005. Human papilloma virus, papanicolaou smears, and the college female. Pediatr Clin North Am 52: 163-177, ix.

10. Burchell AN, Winer RL, de Sanjose S, Franco EL, 2006. Chapter 6: epidemiology and transmission dynamics of genital HPV infection. Vaccine 24 (Suppl 3): S3/52-61.

11. Schiffman M, Kjaer SK, 2003. Chapter 2: natural history of anogenital human papillomavirus infection and neoplasia. $J$ Natl Cancer Inst Monogr 31: 14-19.

12. Plummer M, Schiffman M, Castle PE, Maucort-Boulch D, Wheeler CM, Group A, 2007. A 2-year prospective study of human papillomavirus persistence among women with a cytological diagnosis of atypical squamous cells of undetermined significance or low-grade squamous intraepithelial lesion. $J$ Infect Dis 195: 1582-1589.

13. Rosa MI, Fachel JM, Rosa DD, Medeiros LR, Igansi CN, Bozzetti MC, 2008. Persistence and clearance of human papillomavirus infection: a prospective cohort study. Am J Obstet Gynecol 199: 617 e1-7.

14. Bosch FX, Lorincz A, Munoz N, Meijer CJ, Shah KV, 2002. The causal relation between human papillomavirus and cervical cancer. J Clin Pathol 55: 244-265.

15. Doorbar J, 2018. Host control of human papillomavirus infection and disease. Best Pract Res Clin Obstet Gynaecol 47: 27-41.

16. Hammer A, de Koning MN, Blaakaer J, Steiniche T, Doorbar J, Griffin H, Mejlgaard E, Svanholm H, Quint WG, Gravitt PE, 2019. Whole tissue cervical mapping of HPV infection: molecular evidence for focal latent HPV infection in humans. Papillomavirus Res 7: 82-87.

17. Leonard SM, Pereira M, Roberts S, Cuschieri K, Nuovo G, Athavale R, Young L, Ganesan R, Woodman CB, 2016. Evidence of disrupted high-risk human papillomavirus DNA in morphologically normal cervices of older women. Sci Rep 6: 20847.

18. Gravitt PE, Winer RL, 2017. Natural history of HPV infection across the lifespan: role of viral latency. Viruses 9: 267.

19. Fu TC et al., 2016. Re-detection vs. new acquisition of high-risk human papillomavirus in mid-adult women. Int $J$ Cancer 139: 2201-2212.

20. Paul P, Hammer A, Rositch AF, Burke AE, Viscidi RP, Silver MI, Campos N, Youk AO, Gravitt PE, 2021. Rates of new human papillomavirus detection and loss of detection in middle-aged women by recent and past sexual behavior. J Infect Dis 223: 1423-1432.

21. Rositch AF, Patel EU, Petersen MR, Quinn TC, Gravitt PE, Tobian AAR, 2021. Importance of lifetime sexual history on the prevalence of genital human papillomavirus among unvaccinated adults in NHANES: implications for adult HPV vaccination. Clin Infect Dis 72: e272-e279.

22. Hammer A et al., 2020. A study of the risks of CIN3+ detection after multiple rounds of HPV testing: results of the 15-year cervical cancer screening experience at Kaiser Permanente northern California. Int J Cancer 147: 1612-1620.

23. Miranda PM, Silva NN, Pitol BC, Silva ID, Lima-Filho JL, Carvalho RF, Stocco RC, Becak W, Lima AA, 2013. Persistence or clearance of human papillomavirus infections in women in Ouro Preto, Brazil. BioMed Res Int 2013: 578276. 
24. Schiffman M, Castle PE, Jeronimo J, Rodriguez AC, Wacholder S, 2007. Human papillomavirus and cervical cancer. Lancet 370: 890-907.

25. Fairley CK et al., 1994. Prevalence of HPV DNA in cervical specimens in women with renal transplants: a comparison with dialysis-dependent patients and patients with renal impairment. Nephrol Dial Transplant 9: 416-420.

26. Ozsaran AA, Ates T, Dikmen Y, Zeytinoglu A, Terek C, Erhan Y, Ozacar T, Bilgic A, 1999. Evaluation of the risk of cervical intraepithelial neoplasia and human papilloma virus infection in renal transplant patients receiving immunosuppressive therapy. Eur $J$ Gynaecol Oncol 20: 127-130.

27. Critchlow CW, Hawes SE, Kuypers JM, Goldbaum GM, Holmes KK, Surawicz CM, Kiviat NB, 1998. Effect of HIV infection on the natural history of anal human papillomavirus infection. AIDS 12: 1177-1184.

28. Palefsky JM, Gonzales J, Greenblatt RM, Ahn DK, Hollander H, 1990. Anal intraepithelial neoplasia and anal papillomavirus infection among homosexual males with group IV HIV disease. JAMA 263: 2911-2916.

29. Palefsky JM, Minkoff H, Kalish LA, Levine A, Sacks HS, Garcia P, Young M, Melnick S, Miotti P, Burk R, 1999. Cervicovaginal human papillomavirus infection in human immunodeficiency virus-1 (HIV)-positive and high-risk HIV-negative women. $J$ Natl Cancer Inst 91: 226-236.

30. Luque AE, Demeter LM, Reichman RC, 1999. Association of human papillomavirus infection and disease with magnitude of human immunodeficiency virus type 1 (HIV-1) RNA plasma level among women with HIV-1 infection. J Infect Dis 179: 1405-1409.

31. Eckert LO, Watts DH, Koutsky LA, Hawes SE, Stevens CE, Kuypers J, Kiviat NB, 1999. A matched prospective study of human immunodeficiency virus serostatus, human papillomavirus DNA, and cervical lesions detected by cytology and colposcopy. Infect Dis Obstet Gynecol 7: 158-164.

32. Minkoff H, Feldman J, DeHovitz J, Landesman S, Burk R, 1998. A longitudinal study of human papillomavirus carriage in human immunodeficiency virus-infected and human immunodeficiency virus-uninfected women. Am J Obstet Gynecol 178: 982-986.

33. Sun XW, Kuhn L, Ellerbrock TV, Chiasson MA, Bush TJ, Wright TC Jr., 1997. Human papillomavirus infection in women infected with the human immunodeficiency virus. $N$ Engl $J$ Med 337: 1343-1349.

34. Moscicki AB, Ellenberg JH, Vermund SH, Holland CA, Darragh T, Crowley-Nowick PA, Levin L, Wilson CM, 2000. Prevalence of and risks for cervical human papillomavirus infection and squamous intraepithelial lesions in adolescent girls: impact of infection with human immunodeficiency virus. Arch Pediatr Adolesc Med 154: 127-134.

35. Vernon SD, Unger ER, Piper MA, Severin ST, Wiktor SZ, Ghys PD, Miller DL, Horowitz IR, Greenberg AE, Reeves WC, 1999. HIV and human papillomavirus as independent risk factors for cervical neoplasia in women with high or low numbers of sex partners. Sex Transm Infect 75: 258-260.

36. Scott M, Nakagawa M, Moscicki AB, 2001. Cell-mediated immune response to human papillomavirus infection. Clin Diagn Lab Immunol 8: 209-220.

37. Malejczyk J, Malejczyk M, Kock A, Urbanski A, Majewski S, Hunzelmann N, Jablonska S, Orth G, Luger TA, 1992. Autocrine growth limitation of human papillomavirus type 16-harboring keratinocytes by constitutively released tumor necrosis factoralpha. J Immunol 149: 2702-2708.

38. Woodworth CD, Notario V, DiPaolo JA, 1990. Transforming growth factors beta 1 and 2 transcriptionally regulate human papillomavirus (HPV) type 16 early gene expression in HPVimmortalized human genital epithelial cells. J Virol 64: 47674775.

39. Khan MA, Tolleson WH, Gangemi JD, Pirisi L, 1993. Inhibition of growth, transformation, and expression of human papillomavirus type $16 \mathrm{E} 7$ in human keratinocytes by alpha interferons. $J$ Virol 67: 3396-3403.

40. Kyo S, Inoue M, Hayasaka N, Inoue T, Yutsudo M, Tanizawa O, Hakura A, 1994. Regulation of early gene expression of human papillomavirus type 16 by inflammatory cytokines. Virology 200: 130-139.

41. Scott M, Stites DP, Moscicki AB, 1999. Th1 cytokine patterns in cervical human papillomavirus infection. Clin Diagn Lab Immunol 6: 751-755.

42. Shannon B et al., 2017. Association of HPV infection and clearance with cervicovaginal immunology and the vaginal microbiota. Mucosal Immunol 10: 1310-1319.

43. Pao CC, Lin CY, Yao DS, Tseng CJ, 1995. Differential expression of cytokine genes in cervical cancer tissues. Biochem Biophys Res Commun 214: 1146-1151.

44. al-Saleh W, Giannini SL, Jacobs N, Moutschen M, Doyen J, Boniver J, Delvenne P, 1998. Correlation of T-helper secretory differentiation and types of antigen-presenting cells in squamous intraepithelial lesions of the uterine cervix. J Pathol 184: 283-290.

45. Peghini BC, Abdalla DR, Barcelos AC, Teodoro L, Murta EF, Michelin MA, 2012. Local cytokine profiles of patients with cervical intraepithelial and invasive neoplasia. Hum Immunol 73: 920-926.

46. Clerici M, Merola M, Ferrario E, Trabattoni D, Villa ML, Stefanon B, Venzon DJ, Shearer GM, De Palo G, Clerici E, 1997. Cytokine production patterns in cervical intraepithelial neoplasia: association with human papillomavirus infection. $J$ Natl Cancer Inst 89: $245-250$

47. Tsukui T et al., 1996. Interleukin 2 production in vitro by peripheral lymphocytes in response to human papillomavirus-derived peptides: correlation with cervical pathology. Cancer Res 56: 3967-3974.

48. Hotez PJ, Brindley PJ, Bethony JM, King CH, Pearce EJ, Jacobson J, 2008. Helminth infections: the great neglected tropical diseases. J Clin Invest 118: 1311-1321.

49. Maizels RM, Gomez-Escobar N, Gregory WF, Murray J, Zang X, 2001. Immune evasion genes from filarial nematodes. Int $J$ Parasitol 31: 889-898.

50. Gazzinelli-Guimaraes PH, Nutman TB, 2018. Helminth parasites and immune regulation. F1000 Res 7: 1685.

51. de Ruiter K et al., 2020. Helminth infections drive heterogeneity in human type 2 and regulatory cells. Sci Transl Med 12: eaaw3703.

52. Maizels RM, Pearce EJ, Artis D, Yazdanbakhsh M, Wynn TA, 2009. Regulation of pathogenesis and immunity in helminth infections. J Exp Med 206: 2059-2066.

53. Cortes A, Munoz-Antoli C, Esteban JG, Toledo R, 2017. Th2 and Th1 responses: clear and hidden sides of immunity against intestinal helminths. Trends Parasitol 33: 678-693.

54. Nogueira DS et al., 2016. Multiple exposures to ascaris suum induce tissue injury and mixed Th2/Th17 immune response in mice. PLoS Negl Trop Dis 10: e0004382.

55. Grencis RK, Worthington JJ, 2016. Tuft cells: a new flavor in innate epithelial immunity. Trends Parasitol 32: 583-585.

56. Elliott DE, Weinstock JV, 2012. Helminth-host immunological interactions: prevention and control of immune-mediated diseases. Ann N Y Acad Sci 1247: 83-96.

57. Grainger JR et al., 2010. Helminth secretions induce de novo T cell Foxp3 expression and regulatory function through the TGF-beta pathway. J Exp Med 207: 2331-2341.

58. Sakaguchi S, Miyara M, Costantino CM, Hafler DA, 2010. FOXP3+ regulatory $T$ cells in the human immune system. Nat Rev Immunol 10: 490-500.

59. Blankenhaus B, Klemm U, Eschbach ML, Sparwasser T, Huehn J, Kuhl AA, Loddenkemper C, Jacobs T, Breloer M, 2011. Strongyloides ratti infection induces expansion of Foxp3+ regulatory $T$ cells that interfere with immune response and parasite clearance in BALB/c mice. J Immunol 186: 4295-4305.

60. Sawant DV, Gravano DM, Vogel P, Giacomin P, Artis D, Vignali DA, 2014. Regulatory T cells limit induction of protective immunity and promote immune pathology following intestinal helminth infection. J Immunol 192: 2904-2912.

61. Smith KA, Filbey KJ, Reynolds LA, Hewitson JP, Harcus Y, Boon L, Sparwasser T, Hammerling G, Maizels RM, 2016. Low-level regulatory $T$-cell activity is essential for functional type-2 effector immunity to expel gastrointestinal helminths. Mucosal Immunol 9: 428-443. 
62. Grencis RK, Entwistle GM, 1997. Production of an interferongamma homologue by an intestinal nematode: functionally significant or interesting artefact? Parasitology 115 (Suppl): S101S106.

63. Smith $P$, Mangan NE, Walsh CM, Fallon RE, McKenzie AN, van Rooijen N, Fallon PG, 2007. Infection with a helminth parasite prevents experimental colitis via a macrophage-mediated mechanism. J Immunol 178: 4557-4566.

64. Piessens WF, McGreevy PB, Piessens PW, McGreevy M, Koiman I, Saroso JS, Dennis DT, 1980. Immune responses in human infections with Brugia malayi: specific cellular unresponsiveness to filarial antigens. J Clin Invest 65: 172-179.

65. King CL, Kumaraswami V, Poindexter RW, Kumari S, Jayaraman K, Alling DW, Ottesen EA, Nutman TB, 1992. Immunologic tolerance in lymphatic filariasis. Diminished parasite-specific $T$ and $B$ lymphocyte precursor frequency in the microfilaremic state. J Clin Invest 89: 1403-1410.

66. King CL, Mahanty S, Kumaraswami V, Abrams JS, Regunathan J, Jayaraman K, Ottesen EA, Nutman TB, 1993. Cytokine control of parasite-specific anergy in human lymphatic filariasis. Preferential induction of a regulatory T helper type 2 lymphocyte subset. J Clin Invest 92: 1667-1673.

67. Yazdanbakhsh M, Paxton WA, Kruize YC, Sartono E, Kurniawan A, van het A, Selkirk ME, Partono F, Maizels RM, 1993. T cell responsiveness correlates differentially with antibody isotype levels in clinical and asymptomatic filariasis. $J$ Infect Dis 167: 925-931.

68. Sartono E, Kruize YC, Kurniawan A, van der Meide PH, Partono F, Maizels RM, Yazdanbakhsh M, 1995. Elevated cellular immune responses and interferon-gamma release after longterm diethylcarbamazine treatment of patients with human lymphatic filariasis. J Infect Dis 171: 1683-1687.

69. Harnett W, Harnett MM, 2008. Lymphocyte hyporesponsiveness during filarial nematode infection. Parasite Immunol 30: 447453.

70. Babu S, Nutman TB, 2014. Immunology of lymphatic filariasis. Parasite Immunol 36: 338-346.

71. Mahanty S, Mollis SN, Ravichandran M, Abrams JS, Kumaraswami V, Jayaraman K, Ottesen EA, Nutman TB, 1996. High levels of spontaneous and parasite antigen-driven interleukin-10 production are associated with antigen-specific hyporesponsiveness in human lymphatic filariasis. J Infect Dis 173: 769773.

72. Mahanty S, Ravichandran M, Raman U, Jayaraman K, Kumaraswami V, Nutman TB, 1997. Regulation of parasite antigen-driven immune responses by interleukin-10 (IL-10) and IL-12 in lymphatic filariasis. Infect Immun 65: 17421747.

73. Cooper PJ, Mancero T, Espinel M, Sandoval C, Lovato R, Guderian $\mathrm{RH}$, Nutman TB, 2001. Early human infection with Onchocerca volvulus is associated with an enhanced parasite-specific cellular immune response. J Infect Dis 183: 1662-1668.

74. Doetze A, Satoguina J, Burchard G, Rau T, Loliger C, Fleischer B, Hoerauf A, 2000. Antigen-specific cellular hyporesponsiveness in a chronic human helminth infection is mediated by $\mathrm{T}(\mathrm{h}) 3 / \mathrm{T}(\mathrm{r}) 1$-type cytokines IL-10 and transforming growth factor-beta but not by a $\mathrm{T}(\mathrm{h}) 1$ to $\mathrm{T}(\mathrm{h}) 2$ shift. Int Immunol 12: 623-630.

75. Metenou S, Nutman TB, 2013. Regulatory T cell subsets in filarial infection and their function. Front Immunol 4: 305.

76. Wammes LJ, Hamid F, Wiria AE, Wibowo H, Sartono E, Maizels RM, Smits HH, Supali T, Yazdanbakhsh M, 2012. Regulatory T cells in human lymphatic filariasis: stronger functional activity in microfilaremics. PLoS Negl Trop Dis 6: e1655.

77. Gomez-Escobar N, Lewis E, Maizels RM, 1998. A novel member of the transforming growth factor-beta (TGF-beta) superfamily from the filarial nematodes Brugia malayi and B. pahangi. Exp Parasitol 88: 200-209.

78. Satoguina J, Mempel M, Larbi J, Badusche M, Loliger C, Adjei O, Gachelin G, Fleischer B, Hoerauf A, 2002. Antigen-specific T regulatory-1 cells are associated with immunosuppression in a chronic helminth infection (onchocerciasis). Microbes Infect 4: 1291-1300.
79. Colley DG, Garcia AA, Lambertucci JR, Parra JC, Katz N, Rocha RS, Gazzinelli G, 1986. Immune responses during human schistosomiasis. XII. Differential responsiveness in patients with hepatosplenic disease. Am J Trop Med Hyg 35: 793-802.

80. Grogan JL, Kremsner PG, Deelder AM, Yazdanbakhsh M, 1996. Elevated proliferation and interleukin-4 release from CD4+ cells after chemotherapy in human Schistosoma haematobium infection. Eur J Immunol 26: 1365-1370.

81. King CL et al., 1996. Cytokine control of parasite-specific anergy in human urinary schistosomiasis. IL-10 modulates lymphocyte reactivity. J Immunol 156: 4715-4721.

82. Falcao PL, Malaquias LC, Martins-Filho OA, Silveira AM, Passos VM, Prata A, Gazzinelli G, Coffman RL, Correa-Oliveira $\mathrm{R}, 1998$. Human schistosomiasis mansoni: IL-10 modulates the in vitro granuloma formation. Parasite Immunol 20: 447454.

83. Malaquias LC, Falcao PL, Silveira AM, Gazzinelli G, Prata A, Coffman RL, Pizziolo V, Souza CP, Colley DG, Correa-Oliveira R, 1997. Cytokine regulation of human immune response to Schistosoma mansoni: analysis of the role of IL-4, IL-5 and IL-10 on peripheral blood mononuclear cell responses. Scand J Immunol 46: 393-398.

84. Watanabe K, Mwinzi PN, Black CL, Muok EM, Karanja DM, Secor WE, Colley DG, 2007. T regulatory cell levels decrease in people infected with Schistosoma mansoni on effective treatment. Am J Trop Med Hyg 77: 676-682.

85. Zaccone P, Burton O, Miller N, Jones FM, Dunne DW, Cooke A, 2009. Schistosoma mansoni egg antigens induce Treg that participate in diabetes prevention in NOD mice. Eur J Immunol 39: 1098-1107.

86. Turner JD, Jackson JA, Faulkner H, Behnke J, Else KJ, Kamgno $\mathrm{J}$, Boussinesq M, Bradley JE, 2008. Intensity of intestinal infection with multiple worm species is related to regulatory cytokine output and immune hyporesponsiveness. J Infect Dis 197: 1204-1212.

87. Figueiredo CA, Barreto ML, Rodrigues LC, Cooper PJ, Silva NB, Amorim LD, Alcantara-Neves NM, 2010. Chronic intestinal helminth infections are associated with immune hyporesponsiveness and induction of a regulatory network. Infect Immun 78: 3160-3167.

88. Falcone FH, Rossi AG, Sharkey R, Brown AP, Pritchard DI, Maizels RM, 2001. Ascaris suum-derived products induce human neutrophil activation via a $\mathrm{G}$ protein-coupled receptor that interacts with the interleukin-8 receptor pathway. Infect Immun 69: 4007-4018.

89. Wammes LJ et al., 2016. Community deworming alleviates geohelminth-induced immune hyporesponsiveness. Proc Natl Acad Sci USA 113: 12526-12531.

90. Hartmann S, Lucius R, 2003. Modulation of host immune responses by nematode cystatins. Int J Parasitol 33: 12911302.

91. Broadhurst MJ, Leung JM, Kashyap V, McCune JM, Mahadevan U, McKerrow JH, Loke P, 2010. IL-22 + CD4+ T cells are associated with therapeutic Trichuris trichiura infection in an ulcerative colitis patient. Sci Trans/ Med 2: 60ra88.

92. Correale J, Farez M, 2007. Association between parasite infection and immune responses in multiple sclerosis. Ann Neurol 61: 97-108.

93. Zaiss MM, Harris NL, 2016. Interactions between the intestinal microbiome and helminth parasites. Parasite Immunol 38: 5-11.

94. Macpherson AJ, Harris NL, 2004. Interactions between commensal intestinal bacteria and the immune system. Nat Rev Immunol 4: 478-485.

95. McCoy KD, Burkhard R, Geuking MB, 2019. The microbiome and immune memory formation. Immunol Cell Biol 97: 625-635.

96. Vallianou NG, Tzortzatou-Stathopoulou F, 2019. Microbiota and cancer: an update. $J$ Chemother 31: 59-63.

97. Kather JN, Halama N, 2019. Harnessing the innate immune system and local immunological microenvironment to treat colorectal cancer. Br J Cancer 120: 871-882.

98. McKenney EA, Williamson L, Yoder AD, Rawls JF, Bilbo SD, Parker W, 2015. Alteration of the rat cecal microbiome during 
colonization with the helminth Hymenolepis diminuta. Gut Microbes 6: 182-193.

99. Li RW, Li W, Sun J, Yu P, Baldwin RL, Urban JF, 2016. The effect of helminth infection on the microbial composition and structure of the caprine abomasal microbiome. Sci Rep 6: 20606.

100. Broadhurst MJ et al., 2012. Therapeutic helminth infection of macaques with idiopathic chronic diarrhea alters the inflammatory signature and mucosal microbiota of the colon. PLOS Pathog 8: e1003000.

101. Peachey LE, Jenkins TP, Cantacessi C, 2017. This gut ain't big enough for both of us, or is it? Helminth-microbiota interactions in veterinary species. Trends Parasitol 33: 619-632.

102. Li RW, Wu S, Li W, Navarro K, Couch RD, Hill D, Urban JF Jr., 2012. Alterations in the porcine colon microbiota induced by the gastrointestinal nematode Trichuris suis. Infect Immun 80: 2150-2157.

103. Martin I et al., 2019. The effect of gut microbiome composition on human immune responses: an exploration of interference by helminth infections. Front Genet 10: 1028.

104. Rosa BA et al., 2018. Differential human gut microbiome assemblages during soil-transmitted helminth infections in Indonesia and Liberia. Microbiome 6: 33.

105. Cantacessi C, Giacomin P, Croese J, Zakrzewski M, Sotillo J, McCann L, Nolan MJ, Mitreva M, Krause L, Loukas A, 2014. Impact of experimental hookworm infection on the human gut microbiota. $J$ Infect Dis 210: 1431-1434.

106. Easton AV, Quinones M, Vujkovic-Cvijin I, Oliveira RG, Kepha S, Odiere MR, Anderson RM, Belkaid Y, Nutman TB, 2019. The impact of anthelmintic treatment on human gut microbiota based on cross-sectional and pre- and postdeworming comparisons in western Kenya. MBio 10: e00519.

107. Brosschot TP, Reynolds LA, 2018. The impact of a helminthmodified microbiome on host immunity. Mucosal Immunol 11: 1039-1046.

108. Johnston CJC et al., 2017. A structurally distinct TGF-beta mimic from an intestinal helminth parasite potently induces regulatory T cells. Nat Commun 8: 1741.

109. O'Mahony C et al., 2008. Commensal-induced regulatory T cells mediate protection against pathogen-stimulated NF-kappaB activation. PLoS Pathog 4: e1000112.

110. Round JL, Mazmanian SK, 2010. Inducible Foxp3+ regulatory T-cell development by a commensal bacterium of the intestinal microbiota. Proc Natl Acad Sci USA 107: 1220412209

111. Atarashi $\mathrm{K}$ et al., 2011. Induction of colonic regulatory $\mathrm{T}$ cells by indigenous Clostridium species. Science 331: 337-341.

112. Atarashi $\mathrm{K}$ et al., 2013. Treg induction by a rationally selected mixture of Clostridia strains from the human microbiota. Nature 500: 232-236.

113. Narushima S, Sugiura $Y$, Oshima K, Atarashi K, Hattori M, Suematsu M, Honda K, 2014. Characterization of the 17 strains of regulatory $\mathrm{T}$ cell-inducing human-derived Clostridia. Gut Microbes 5: 333-339.

114. Smits HH et al., 2005. Selective probiotic bacteria induce IL-10producing regulatory $T$ cells in vitro by modulating dendritic cell function through dendritic cell-specific intercellular adhesion molecule 3-grabbing nonintegrin. J Allergy Clin Immunol 115: 1260-1267.

115. Jang SO, Kim HJ, Kim YJ, Kang MJ, Kwon JW, Seo JH, Kim HY, Kim BJ, Yu J, Hong SJ, 2012. Asthma prevention by lactobacillus rhamnosus in a mouse model is associated with CD4(+)CD25(+)Foxp3(+) T cells. Allergy Asthma Immunol Res 4: 150-156.

116. Ohnmacht $C$ et al., 2015. MUCOSAL IMMUNOLOGY. The microbiota regulates type 2 immunity through RORgammat(+) T cells. Science 349: 989-993.

117. Rausch S, Held J, Fischer A, Heimesaat MM, Kuhl AA, Bereswill S, Hartmann S, 2013. Small intestinal nematode infection of mice is associated with increased enterobacterial loads alongside the intestinal tract. PLoS One 8: e74026.

118. Kreisinger J, Bastien G, Hauffe HC, Marchesi J, Perkins SE, 2015. Interactions between multiple helminths and the gut microbiota in wild rodents. Philos Trans $R$ Soc Lond B Biol Sci 370: 20140295

119. Reynolds LA, Smith KA, Filbey KJ, Harcus Y, Hewitson JP, Redpath SA, Valdez Y, Yebra MJ, Finlay BB, Maizels RM, 2014. Commensal-pathogen interactions in the intestinal tract: Lactobacilli promote infection with, and are promoted by, helminth parasites. Gut Microbes 5: 522-532.

120. Graham AL, 2008. Ecological rules governing helminthmicroparasite coinfection. Proc Natl Acad Sci USA 105: 566570.

121. Salgame P, Yap GS, Gause WC, 2013. Effect of helminthinduced immunity on infections with microbial pathogens. Nat Immunol 14: 1118-1126.

122. Chen CC, Louie S, McCormick B, Walker WA, Shi HN, 2005. Concurrent infection with an intestinal helminth parasite impairs host resistance to enteric Citrobacter rodentium and enhances Citrobacter-induced colitis in mice. Infect Immun 73: 54685481.

123. Reese TA et al., 2014. Helminth infection reactivates latent gamma-herpesvirus via cytokine competition at a viral promoter. Science 345: 573-577.

124. Osborne LC et al., 2014. Coinfection. Virus-helminth coinfection reveals a microbiota-independent mechanism of immunomodulation. Science 345: 578-582.

125. Gazzinelli-Guimaraes PH et al., 2017. Concomitant helminth infection downmodulates the vaccinia virus-specific immune response and potentiates virus-associated pathology. Int J Parasitol 47: 1-10.

126. Veldhoen M, Heeney JL, 2014. A helminth-mediated viral awakening. Trends Immunol 35: 452-453.

127. Damania B, Dittmer DP, 2014. What lies within: coinfections and immunity. Cell Host Microbe 16: 145-147.

128. Shapira-Nahor O, Kalinkovich A, Weisman Z, Greenberg Z, Nahmias J, Shapiro M, Panet A, Bentwich Z, 1998. Increased susceptibility to HIV-1 infection of peripheral blood mononuclear cells from chronically immune-activated individuals. AIDS 12: 1731-1733.

129. Chachage $M$ et al., 2014. Helminth-associated systemic immune activation and HIV co-receptor expression: response to albendazole/praziquantel treatment. PLOS Negl Trop Dis 8: e2755.

130. Secor WE, Shah A, Mwinzi PM, Ndenga BA, Watta CO, Karanja DM, 2003. Increased density of human immunodeficiency virus type 1 coreceptors CCR5 and CXCR4 on the surfaces of CD4(+) T cells and monocytes of patients with Schistosoma mansoni infection. Infect Immun 71: 6668-6671.

131. Borkow G, Bentwich Z, 2006. HIV and helminth co-infection: is deworming necessary? Parasite Immunol 28: 605-612.

132. Bentwich Z, Weisman Z, Moroz C, Bar-Yehuda S, Kalinkovich A, 1996. Immune dysregulation in Ethiopian immigrants in Israel: relevance to helminth infections? Clin Exp Immunol 103: 239243.

133. Blish CA, Sangare L, Herrin BR, Richardson BA, John-Stewart G, Walson JL, 2010. Changes in plasma cytokines after treatment of Ascaris lumbricoides infection in individuals with HIV-1 infection. J Infect Dis 201: 1816-1821.

134. Borkow G, Teicher C, Bentwich Z, 2007. Helminth-HIV coinfection: should we deworm? PLoS Negl Trop Dis 1: e160.

135. Means AR, Burns P, Sinclair D, Walson JL, 2016. Antihelminthics in helminth-endemic areas: effects on HIV disease progression. Cochrane Database Syst Rev 4: CD006419.

136. Nalwoga A et al., 2019. Kaposi's sarcoma-associated herpesvirus seropositivity is associated with parasite infections in Ugandan fishing communities on Lake Victoria islands. PLoS Negl Trop Dis 13: e0007776.

137. Passmore JS, Williamson A, 2016. Host immune responses associated with clearance or persistence of human papillomavirus infections. Curr Obstet Gynecol Rep 5: 177-188.

138. Tristram A, Fiander A, 2001. Natural history of cervical human papillomavirus. Lancet 358: 1550.

139. Egawa N, Egawa K, Griffin H, Doorbar J, 2015. Human papillomaviruses; epithelial tropisms, and the development of neoplasia. Viruses 7: 3863-3890. 
140. van Riet E, Hartgers FC, Yazdanbakhsh M, 2007. Chronic helminth infections induce immunomodulation: consequences and mechanisms. Immunobiology 212: 475-490.

141. Lo NC, Lai YS, Karagiannis-Voules DA, Bogoch II, Coulibaly JT, Bendavid E, Utzinger J, Vounatsou P, Andrews JR, 2016. Assessment of global guidelines for preventive chemotherapy against schistosomiasis and soil-transmitted helminthiasis: a costeffectiveness modelling study. Lancet Infect Dis 16: 1065-1075.
142. WHO, 2018. Reaching Girls and Women of Reproductive Age with Deworming: Report of the Advisory Group on Deworming in Girls and Women of Reproductive Age. Rockefeller Foundation Bellagio Center, Bellagio, Italy 28-30 June 2017. Montresor A, ed. Geneva, Switzerland: World Health Organization.

143. Rowan-Nash AD, Korry BJ, Mylonakis E, Belenky P, 2019. Cross-domain and viral interactions in the microbiome. Microbiol Mol Biol Rev 83: e00044-18. 